\title{
E-Cigarettes: Risk Assessment and Possible uses for Patients with Severe COPD - An Update
}

\author{
Thomas Hering* \\ Pulmonology Clinic, Germany
}

Submission: February 13, 2017; Published: February 20, 2017

*Corresponding author: Thomas Hering, Head Physician, Pulmonology Clinic, Schloßstraße 5, 13507 Berlin, Germany, Europe, Tel: +49 30 32601511; Email: hering@t-online.de

\section{Mini Review}

Taking market data as a basis, e-cigarettes continue to enjoy major success [1]. Topulmonologists it falls to assess this development, to advise patients adequately and if appropriate to support their use. Even though for long-term risk assessment the state of information is still unsatisfactory, their use has become increasingly established. The clearest statement has been that of the Public Health Authority of the British government: this clear statement published 2015 on e-cigarettes classified their global risk as extremely positive compared to tobacco cigarettes. The risk from consumption of e-cigarettes is assessed as one twentieth of the risk of tobacco cigarettes [2]. According to this, in a hypothetical world where only e-cigarettes were consumed instead of tobacco cigarettes, after the dropping of tobaccorelated morbidity and mortality - the mortality would drop by $95 \%$. Instead of the now roughly120 thousand tobacco-related deaths eg. in Germany [3], we would be left with only 6000 "e-cigarettes-deaths." That is according to the hypothesis, which speaks for itself.

But how should pulmonologists classify their use in consultations, how should they advise patients?

Two significant arguments against e-cigarettes state that they constitute

a. A potential gateway drug for youth...

b. A potential risk of cancer from e-cigarette substances, even if it is less...

Clearly these arguments cannot be brushed off without further consideration. On the other hand: for which patients, from the treating pneumologist's perspective, would switching

to e-cigarette need to be considered? It is first and foremost those patients who already have advanced COPD - according to the current GOLD-Classification [4] 4B or 3B i.e, those with severely restricted lung functioning and significant symptoms, for whom we must most urgently ensure that further exposure of bronchial system to toxic smoke is prevented. As a rule it is always important that a complete, effective breaking of the tobacco addiction without fallbacks would be the first priority $[4,5]$.

But what if breaking the tobacco addition is not a realistic alternative? We all know how great the challenge is in order to actually break the tobacco addiction, beginning from the challenges that the lawmakers and the health insurers impose, to the challenges represented by the limited own resources of the patients in cases of severe addiction. Tobacco consumption is in large part now mostly a problem of the educationally deprived classes [6]. For patients in this situation with extremely advanced COPD mostly at advanced ages, the abovementioned counterarguments ("potential gateway drug" and "potential risk of bronchial carcinoma") are scarcely to be adduced.

Thus it is important, in cases of a strong urge to smoke, if there is no realistic chance of overcoming tobacco addiction, that the e-cigarette be a feasible alternative [7]. The latest studies and recommendations show that modern products are superior in ensuring the nicotine dosage [8]. It is important to recommend to patients with high degrees of nicotine dependence an e-cigarette that provides sufficient nicotine in order to hinder the impulse to fall back on tobacco cigarettes.

\section{References}

1. Hillienhof, Arne (2017) E-Shishas und E-Zigaretten: Umsatze weisen steil nach oben. Dtsch Arztebl 114(3): A-68/B-61/C-61.

2. McNeill A, brose Ls, Calder R, Hitchman SC, Hajek P et al. (2015) E-cigarettes: an evidence update - A report commissioned by Public Health England. Protecting and improving the nation's health, PHE Publications.

3. Juni (2016) Drogen- Und Suchtbericht Vorgestellt. Drogenbeauftragte der bundesregierung.

4. Claus F Vogelmeir, Gerald J Criner, Fernando J martinez, Antonio Anzueto, Peter J Barnes et al. (2017) Global Strategy For The Diagnosis, 
Management And Prevention of Chronic Obstructive Pulmonary Disease. American Journal of Respiratory and Critical Care Medicine, Newyork, USA, 187(4).

5. Andreas S, Batra A, Behr J, Chenot JF, Gillissen et al. (2014) Smoking cessation in patients with COPD. Pneumologie 68(4): 237-258.

6. Grusswort (2015) Gesundheit in Deutschland. Robert Koch Institut.

7. Nowak D, Gohlke H, Hering T, Herth FJ, Jany B et al. (2015) Position paper of the German Respiratory Society (DGP) on electronic cigarettes (E-cigarettes) in cooperation with the following scientific societies and organisations: BVKJ, BdP, DGAUM, DGG, DGIM, DGK, DKG, DGSMP, GPP. Pneumologie 69(3): 131-134.

8. Hajek P, Dunja Przulj, Anna Phillips, Rebecca Anderson, Hayden McRobbie et al. (2017) Nicotine delivery to users from cigarettes and from different types of e-cigarettes. Psychopharmacology, Open Science aggregated, Paperity.

\section{Your next submission with Juniper Publishers} will reach you the below assets

- Quality Editorial service

- Swift Peer Review

- Reprints availability

- E-prints Service

- Manuscript Podcast for convenient understanding

- Global attainment for your research

- Manuscript accessibility in different formats ( Pdf, E-pub, Full Text, Audio)

- Unceasing customer service

Track the below URL for one-step submission https://juniperpublishers.com/online-submission.php 